Proceeding ICOGISS 2019

Page 602-614. ISBN: 978-602-6 988-75-1

Web Jurnal Online: jurnal.unmuhjember.ac.id

By: Dian Eka Rahmawati; Samini

Collaborative Governance Perspective In The Development of Micro Small and Medium

Businesses (UMKM) in Bantul Regency 2017-2018

\title{
COLLABORATIVE GOVERNANCE PERSPECTIVE IN THE DEVELOPMENT OF MICRO SMALL AND MEDIUM BUSINESSES (UMKM) IN BANTUL REGENCY 2017-2018
}

\author{
By: Dian Eka Rahmawati, Samini \\ Governmental Science, Universitas Muhammadiyah Yogyakarta \\ Email: dianekarahmawati93@gmail.com
}

\begin{abstract}
This article aims to analyze the efforts of the Bantul Regency Government in the development of Micro, Small and Medium Businesses (UMKM) with the perspective of collaborative governance. Bantul Regency is one of the Regencies in the Special Province of Yogyakarta with the increasing number of UMKM, especially in the field of crafts. However, various obstacles are still faced by craftsmen. Recognizing that the government has limitations in developing UMKM, a collaborative perspective with various interested and competent parties becomes a necessity. The study was conducted using qualitative descriptive research methods. Data collection techniques using documentation and interviews. Data analysis techniques are carried out through the stages of data reduction, data display, and conclusion drawing. The results of eight indicators of the collaborative governance process showed: 1) the network structure involved 3 actors, namely the Office of Cooperatives, UKM, and Industry, PT Telkom, and craftsmen. Network structure and communication patterns are horizontal, each actor is in an equal position, there is no vertical hierarchy, all network members have the same position. 2) Commitment to a common purpose is based on the purpose of developing the craft industry. Commitments between the Cooperative, UKM, and Industry Service with PT. Telkom were agreed in the form of the MoU and the UKM Digital Village Program. While the commitment of the craftsmen experienced a weakening because the problem of product marketing was not resolved with the existence of the program. 3) Trust among participants is built through communication, but from the handicraftsmen they experience a decrease in trust in other actors because the programs implemented cannot solve their problems and there are no other more effective solutions. 4) Governance is regulated through collaborative implementation regulations namely Law no.20 of 2008, regent regulation No.81 of 2015, and MoU between Cooperative, UKM, and Industry Services with PT. Telkom number: 92 / PK / BT / year 2016/2017 which is valid until 2019. 5) Access to authority is indicated by the existence of clear procedures and authority between the three actors in the program. 6) Distributive accountability and responbility is dominated by the Office of Cooperatives, UKM, and Industry. 7) Information sharing is done formally and informally, also through social media. 8) Access to resources experiences limitations from aspects of human resources from the Cooperative, UKM, and Industry Service as well as from craftsmen. Thus, it can be concluded that collaborative governance in the development of UMKM in Bantul Regency in 2017-2018 has been processed but has not been maximized, so there is still a need for improvement in several indicators in order to achieve the goal of collaborating the development of UMKM.
\end{abstract}

Kata Kunci: Collaborative Governance, UMKM Development 
Proceeding ICOGISS 2019

Page 611-623. ISBN: 978-602-6 988-75-1

Web Jurnal Online: jurnal.unmuhjember.ac.id

By: Dian Eka Rahmawati; Samini

Collaborative Governance Perspective In The Development of Micro Small and Medium

Businesses (UMKM) in Bantul Regency 2017-2018

\section{INTRODUCTION}

Definition of Micro, Small, and Medium Enterprises (UMKM) according to Act Number 20 of 2008 is a productive economic enterprise owned by individuals or individual business entities, not a subsidiary or branch of a company that has family principles, economic democracy, togetherness, efficiency fairness, sustainability, environmental insight, independence, balance of progress, and national economic unity. UMKM are labor intensive businesses, which do not require certain requirements such as education levels, workers' skills (skills), and relatively little business capital and the technology used tends to be simple (Badruddin, 2012). UMKM become business activities that are able to encourage economic growth, expand employment, provide broad economic services to the community, and play a role in the process of equity and increasing income for the community. UMKM are one of the main pillars of the national economy which must obtain the greatest opportunity, support, protection and development as widely as possible as a form of firm alignment to the people's economic business groups (Dwiyanto, 2011).

UMKMs are one of the economic sectors capable of surviving the economic crisis. Based on data obtained from Bank Indonesia (2015), at the time of the 1998 monetary crisis and the 2008 to 2009 crisis, as many as $96 \%$ of UMKMs were able to withstand the shock of the crisis. Meanwhile, data obtained from the Ministry of Cooperatives and Small and Medium Enterprises of the Republic of Indonesia shows that in 2012-2013 the total Gross Domestic Product (GDP) was Rp. 9,014.9 trillion, the UMKM sector contributed Rp. 5,440.0 trillion or 60.34\%. The number of MSMEs in Indonesia reached 57.89 million units or $99.99 \%$ of the total business units in Indonesia. While the number of workers reached 114.14 million people or $96.99 \%$ of all workers in Indonesia. (http://www.depkop.go.id/berita-informasi/data-informasi/data-umkm). From the data above it can be seen that UMKMs have a strategic role in contributing income and employment in Indonesia. Therefore, the development of UMKMs is one of the government's strategies to improve the economy and reduce poverty.

Bantul Regency is one of the districts in the Special Province of Yogyakarta which has experienced a rapid increase in the development of UMKMs, especially in the fields of industry and creative crafts. The growth of UMKMs in the Bantul Regency over the past three years can be seen in the table below:

Table 1

Growth of UMKMs in Bantul Regency 2016-2018

\begin{tabular}{|l|l|l|l|l|}
\hline No & Description & 2016 & 2017 & 2018 \\
\hline 1 & Mikro Business & 27.708 & 27.828 & 28.384 \\
\hline 2 & Small Business & 11.544 & 11.594 & 11.768 \\
\hline 3 & Medium Business & 6.926 & 6.959 & 6.991 \\
\hline & Total & 46.178 & 46.378 & 47.143 \\
\hline
\end{tabular}

Sources: processed from the Office of Cooperative, UKM, and Industry, 2018. 
Proceeding ICOGISS 2019

Page 611-623. ISBN: 978-602-6 988-75-1

Web Jurnal Online: jurnal.unmuhjember.ac.id

By: Dian Eka Rahmawati; Samini

Collaborative Governance Perspective In The Development of Micro Small and Medium

Businesses (UMKM) in Bantul Regency 2017-2018

Based on the table above, it can be seen that the number of UMKMs increases in Bantul Regency from year to year. In 2018, growth was quite high. However, various obstacles are still faced by craftsmen, especially the issues of product development, marketing, and capital. Realizing that the government has limitations in developing UMKMs, the Bantul Regency Government collaborates with the private sector, in this case PT. Telkom through the UKM Digital Village program as an effort to overcome problems and expand marketing. Based on the background above, this article will be focused on analyzing collaborative governance between the Office of Cooperatives, UKM, and Industry with PT. Telkom, and craft industry players in Bantul Regency use the Collaborative Process model and indicators proposed by DeSeve.

\section{THEORITICAL FRAMEWORK}

Collaborative governance appears to be a new strategy in governance reform. This approach places stakeholders together in a forum similar to public institutions, to engage in consensus-oriented decision making (Ansell and Gash, 2008).

Collaborative governance includes formal and informal relationships in problem solving and decision making. Conventional government policies can be expanded by facilitating collaboration between the public sector, the private sector and society. Therefore, several requirements are needed in collaborative governance, namely: support, leadership, and forums. Support helps at the stage of identifying problems, leadership brings the results of problem identification into the forum, then forum members collaborate to produce policies, solutions, and answers to problems that have been identified previously.

Emerson (2012) describes several criteria contained in this approach, namely:

1) The existence of a forum initiated by public institutions or the government.

2) The presence of participants in the forum involving non-government actors.

3) Participants are involved and bound in making decisions.

4) Forums are formally organized.

5) The forum aims to make decisions through consensus.

6) Focus on collaboration on public policy or public management.

One of the collaborative governance models proposed by Anshell and Gash (2008) is Collaborative Process. The Collaborative Process Model describes collaboration as a developmental stage. Gray (in Harmawan, 2016) identifies several stages in Collaborative Process:

1) Trust building. The existence of trust between actors is the beginning of the collaboration process. Trust building is a phase that is used to form a process of mutual understanding among stakeholders to form a commitment to carry out collaboration.

2) Commitment to process. Commitment to collaboration is the main variable in explaining the success or failure of a collaboration. Commitment is closely related to the motivation to participate in collaborative governance. Collaborative governance can form a sense of ownership of decision making from agency or government agencies to stakeholders acting collectively. 
Proceeding ICOGISS 2019

Page 611-623. ISBN: 978-602-6 988-75-1

Web Jurnal Online: jurnal.unmuhjember.ac.id

By: Dian Eka Rahmawati; Samini

Collaborative Governance Perspective In The Development of Micro Small and Medium

Businesses (UMKM) in Bantul Regency 2017-2018

3) Share understanding. An attitude of mutual understanding of what will be achieved together. The sharing understanding in several literacies is referred to as a shared mission, similarity of intentions, common goals, common vision, shared ideology, clear objectives, strategic direction and clear or harmonious core values. Share understanding also means agreement in defining a problem.

4) Intermediate outcomes. Many case studies show that collaboration can be relatively concrete when there is a possibility of success. Although these intermediate outcomes will display output, these outcomes processes are the essence of building momentum that can lead to successful collaboration. Intermediate outcomes cannot be generalized as the final results achieved.

Furthermore DeSeve in Sudarmo (2011) made several indicators to measure the governance collaboration process, namely:

1) Network structure. Explaining about the relationship between one element and the other elements that are united together by describing the physical elements of the network handled.

2) Commitment to a common purpose. Referring to the reason why a network must be held. The need for attention and commitment to achieve positive goals or expected goals.

3) Trust among the participants. The mutual trust between actors involved in the network is based on professional or social relations. Participants entrust information and efforts from other stakeholders in a network to achieve common goals.

4) Governance. Regulations that govern collaboration that will be carried out, related regulations in an effort to run the program implemented, clear agreed upon rules of the game, freedom to determine how collaboration can be carried out.

5) Access to autority. Availability of standard provisions or procedures that are clear and widely accepted, the authority to implement decisions in carrying out their work.

6) Distributive accountability. Sharing arrangement, management, management together with other stakeholders and sharing decision making to all network members to achieve the desired results to the full.

7) Information sharing. Ease of access to information for members, protection of the privacy of one's personal identity, and limited access for non-members as long as it can be accepted by all parties, covering all systems, software and procedures that are easy and safe to access information.

8) Access to resources. Availability of financial, technical, human and other resources needed to achieve network goals.

\section{RESEARCH METHODS}

This study uses qualitative methods with descriptive research types. According to Rahmawati (2014: 13) descriptive qualitative research is a study that produces descriptive data in the form of words or writings from someone against something that is being 
Proceeding ICOGISS 2019

Page 611-623. ISBN: 978-602-6 988-75-1

Web Jurnal Online: jurnal.unmuhjember.ac.id

By: Dian Eka Rahmawati; Samini

Collaborative Governance Perspective In The Development of Micro Small and Medium

Businesses (UMKM) in Bantul Regency 2017-2018

observed in the field. Qualitative research aims to understand a phenomenon holistically and not isolate an individual or organization into variables and not aim to test the hypothesis.

Primary data is obtained through interviews with parties involved in collaboration, namely: Office of Cooperatives, UKM, and Industry, PT. Telkom, and craftsmen in Sanden District, Bantul Regency. Secondary data was obtained through various documentation, namely: various references related to research both in the form of journals and books, LPJ from Cooperative, UKM, and Industry Services, and information from the website of the Bantul Regency Government and PT. Telkom. The data that has been obtained is then analyzed through the stages of data reduction, data display, and conclusion

\section{DISCUSSION}

UMKMs in Bantul Regency have a large role in improving the economy and absorbing workers. This can be seen from the data on employment absorption from the UMKM sector which continued to increase from 2016 to 2018 in the table below:

Table 2

Absorbing Worker in UMKM Sector in Bantul Regency 2016-2018

\begin{tabular}{|l|l|l|l|l|}
\hline No & Description & 2016 & 2017 & 2018 \\
\hline 1 & Mikro Business & 55.416 & 55.656 & 56.768 \\
\hline 2 & Small Business & 34.632 & 34.782 & 35.130 \\
\hline 3 & Medium Business & 6.926 & 6.956 & 111.856 \\
\hline & Total & 200.864 & 201.734 & 203.754 \\
\hline
\end{tabular}

Sources: processed from the Office of Cooperative, UKM, and Industry, 2018.

Among the various MSMEs, the handicraft industry has become a MSME sector that is very much felt in the governance of people's lives because its distribution is almost evenly distributed in all regions in Bantul Regency. About $60 \%$ of total craft exports in DIY are produced by Bantul craftsmen (https://bantulkab.go.id). The handicraft industry that is quite prominent in Bantul Regency is a creativity-based craft industry or creative industry, even in 2017 Bantul Regency received an award as the Mandiri Kreatif Regency Craft Sector.

Based on data from the Department of Cooperatives, Small and Medium Enterprises, and Industry of Bantul Regency until the end of 2017 there were $78 \mathrm{craft}$ industry centers, including batik crafts, sungging tatah crafts, knitting crafts, wooden crafts, water hyacinth crafts, clay crafts, shell crafts coconut, and many other handicraft products that have become superior products of the local area. https://bantulkab.go.id. The data in the table below shows the scope of the creative craft industry in Bantul Regency compared to other craft industry sectors which increased from 2016 to 2018. 
Proceeding ICOGISS 2019

Page 611-623. ISBN: 978-602-6 988-75-1

Web Jurnal Online: jurnal.unmuhjember.ac.id

By: Dian Eka Rahmawati; Samini

Collaborative Governance Perspective In The Development of Micro Small and Medium

Businesses (UMKM) in Bantul Regency 2017-2018

Table 3

Coverage of Bantul Regency Creative Industry 2016-2018

\begin{tabular}{|l|l|l|}
\hline No & Year & Percentage of Achievement \\
\hline 1 & 2016 & $39,5 \%$ \\
\hline 2 & 2017 & $41,11 \%$ \\
\hline 3 & 2018 & $42,90 \%$ \\
\hline
\end{tabular}

Sources: processed from the Office of Cooperative, UKM, and Industry, 2018.

One of the creative craft centers in the craft sector in Bantul Regency is coconut shell crafts in Sanden District. The idea of coconut shell craft originated from the large amount of coconut shell waste produced from the raw materials of the typical Bantul food industry. There are two types of products produced, namely handicrafts and furniture. One of the craftsmen who has been in the craft field for 10 years said he could earn around 8-10 million per production, assisted by 10 workers (interview with Mr. Iin, coconut shell craftsmen, December 27, 2018). From the results of interviews with one of the UMKM facilitators in Sanden District, data was obtained that coconut shell craftsmen had been able to produce handicrafts with an average production capacity per month reaching 1000 pieces and involving 15-30 craftsmen in one industrial center (interview with Mrs. Desi, companion UMKMs in Sanden District, 3 December 2018). However, in general the craftsmen still faced obstacles especially in product development, marketing and capital creativity. This condition needs attention from the local government (interview with Mr. Heri, coconut shell craftsman, December 27, 2018).

The Regional Government of Bantul Regency, through the Office of Cooperatives, Small and Medium Enterprises, and Industry has collaborated with several parties to develop UMKMs, among others, with PT. Telkom through the UKM Digital Village Program. One of the activities in the UKM Digital Village Program is ecommerce marketing, namely marketing and sales services that can be done online to penetrate national and global markets. The Digital UKM Village Program is an UKM community empowerment program through efforts to encourage the use of information and communication technology. The Digital UKM village in Bantul facilitated by an optical cable network from PT Telkom has been started since August 2016 with implementation centered on craft centers in Bantul Regency (interview with Mr. Affun, Industrial Facilities and Infrastructure Staff from the UKM and District Industry Cooperative Office Bantul, 4 December 2018).

The collaborative governance process between the Office of Cooperatives, UKM, and Industry, PT Telkom, and the coconut shell craft UKM can be seen using indicators that influence collaboration presented by DeSeve (2007) and the following results are obtained:

\section{Network Structure}

The network structure in this collaboration involves three actors, namely the Office of Cooperatives, UKM, and Industry in Bantul Regency, PT. Telkom, and the coconut shell industry centers in the UKM Digital Village Program. Network structure 
Page 611-623. ISBN: 978-602-6 988-75-1

Web Jurnal Online: jurnal.unmuhjember.ac.id

By: Dian Eka Rahmawati; Samini Collaborative Governance Perspective In The Development of Micro Small and Medium

Businesses (UMKM) in Bantul Regency 2017-2018

and communication patterns are horizontal, each actor is in an equal position, there is no hierarchy in a vertical manner, all have roles based on tupoksi and authority. This indicates a good network structure as intended in collaborative governance. However, because the UKM Digital Village Program originated from a collaboration between the Office of Cooperatives, UKM, and Industry with PT. Telkom, the flow of communication comes more from the two actors than the craftsmen.

Figure 1

Network Structure Among Actors in UKM Digital Village Program

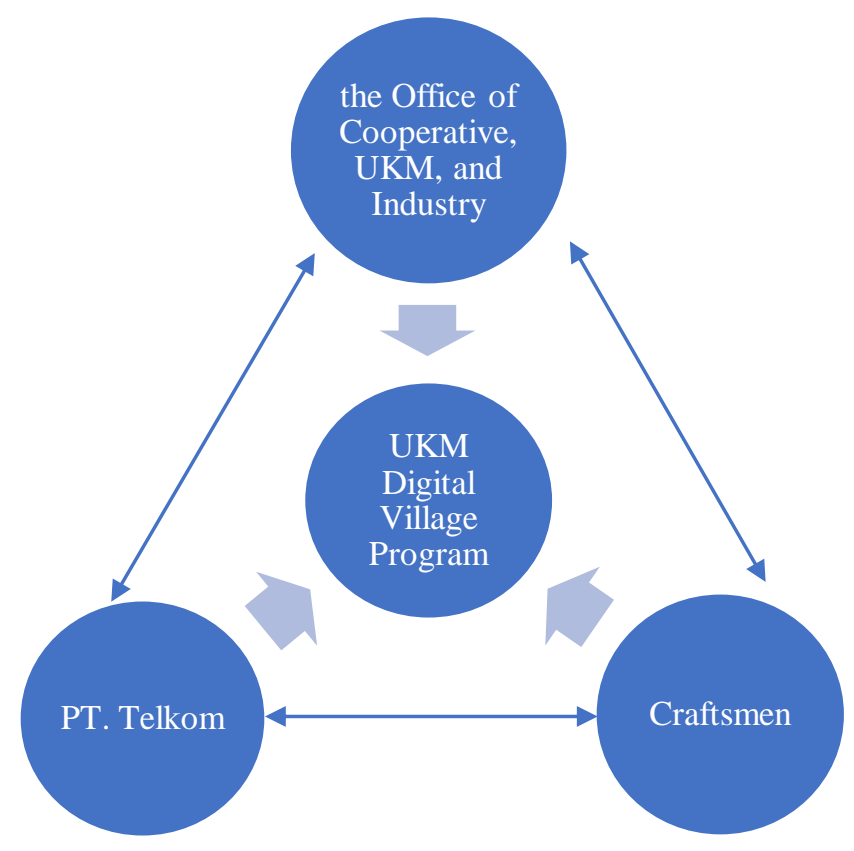

\section{Commitment to a Common Purpose}

Collaboration between the Office of Cooperatives, UKM, and Industry in Bantul Regency, PT. Telkom, and the coconut shell industry players are based on the common goal of developing the coconut shell industry UMKMs. Commitment to achieve common goals is built by the Office of Cooperatives, UKM and Industry and PT Telkom through their vision and mission. Furthermore, this commitment was more specifically stated in the MoU. While the commitment of the craftsmen is not written in writing, but in the form of trust in the UKM Digital Village Program, which is evident from their involvement in socialization and implementation of the program (interview with Ms. Tri Murdianani SE, MM, Head of Industrial Structures and Infrastructure, December 4 2018). Commitments among the three collaborative actors also emerged in the form of joint efforts to find solutions to the various obstacles faced in the program. However, some obstacles experienced by some craftsmen because e-commerce marketing methods offered in the UKM Digital Village program are not easy to follow. Mastery of information technology is still an obstacle for some craftsmen, so in the end many are 
Proceeding ICOGISS 2019

Page 611-623. ISBN: 978-602-6 988-75-1

Web Jurnal Online: jurnal.unmuhjember.ac.id

By: Dian Eka Rahmawati; Samini

Collaborative Governance Perspective In The Development of Micro Small and Medium

Businesses (UMKM) in Bantul Regency 2017-2018

returning to conventional marketing methods. This resulted in a weakening commitment from craftsmen to the UKM Digital Village Program (interview with Mr. Iin, coconut shell craftsmen, December 27, 2018).

\section{Trust Among the Participants}

In addition to the strong commitment needed to the common goal, collaboration also requires trust between the actors involved. Both of these factors influence each other. Before cooperating, between the Cooperative, SME and Industry Services with stakeholders have made an assessment. This form of trust was implemented through the agreed MoU and UKM Digital Village program (interview with Mr. Affun, staff of the Industrial Infrastructure \& Facilities, 24 December 2018). Trust between actors is built and maintained through communication. The Office of Cooperatives, SMEs, and Industry invites craftsmen to inventory various issues related to the development of the craft industry and find solutions to existing problems through the Focus Group Disscussion (FGD) forum. The activity is held regularly at the Office of Cooperatives, SMEs, and Industry and also in the Sanden Sub-district office (interview with Ms. Tri Murdianani, S.E., M.M., Head of Industrial Infrastructure and Facilities and as the former Head of Cooperatives, November 5, 2018). This was felt by some artisans, but not all product marketing problems were resolved through the UKM Digital Village Program. Some craftsmen see that there is no effective solution in solving product marketing problems which results in reduced craftsman confidence in the Cooperative, SME, and Industry Office and the program (interview with Mr. Isnaini, coconut shell craftsman, December 27, 2018).

\section{Governance}

Governance is related to the regulations governing collaboration that are carried out. The reference regulation is Law No. 20 of 2008 concerning UMKMs which was then operationalized by Regent Regulation No. 81 of 2015 concerning UMKM licensing authority, which regulates legal legality in business licensing and protection. Furthermore, there is a Memorandum of Understanding (MoU) in the industrial development collaboration process. creative in Sanden Subdistrict, as recorded in the cooperation agreement between the Bantul Regency Government and PT. Telekomunikasi Indonesia, TBK with number: 92 / PK / BT / year 2016/2017 about efforts to develop UMKMs. This cooperation agreement is to carry out a joint agreement between the Government of Bantul and PT. Telkom number 44 / MoU / BT / 2017. In accordance with existing regulations, collaboration carried out by the Office of Cooperative, UKM, and Industry of Bantul Regency in the effort to develop this creative industry has a period of 2 years until 2019 (interview with Mr. Juwahir, SE, MM, Head of Small and Medium Enterprises, 5 December 2018)

\section{Access to Authority}

Access to authority is related to the availability of clear procedures and authority to implement decisions. In this collaboration there are procedures for implementing 
Proceeding ICOGISS 2019

Page 611-623. ISBN: 978-602-6 988-75-1

Web Jurnal Online: jurnal.unmuhjember.ac.id

By: Dian Eka Rahmawati; Samini

Collaborative Governance Perspective In The Development of Micro Small and Medium

Businesses (UMKM) in Bantul Regency 2017-2018

programs in accordance with the authority of each actor. The authority of the Cooperative, UKM, and Industry Service is related to the implementation of Law No. 20 of 2008 concerning UMKMs. The service has the authority and authority to implement policies in terms of making technical rules and collaboration patterns. PT. Telkom has the authority and authority to provide digital infrastructure and access to information delivery for policy making. Craftsmen have access to get digital marketing facilities and access to deliver information for policy making through various joint forums (interview with Ms. Tri Murdianani, S.E., M.M, Head of Industrial Infrastructure and Facilities, December 4, 2018). The data was also strengthened from the results of interviews with Mr. Ade (Head of PT Telkom's Responsiveness Division), Mr. Isnaini, Mr. Heri, and Mr. Iin (coconut shell craftsmen) who stated the same thing.

\section{Distributive Accountability/Responsibility}

Distributive accountability or responbility is related to sharing arrangement and management and sharing decision making to all network members to achieve the desired results to the full. This indicator is also related to access to authority indicators because the management division and decision making are based on the authority of each actor and work procedures that have been mutually agreed upon in the UKM Digital Village Program. Decisions taken in this collaboration process involve all actors, but the Office of Cooperative, UKM, and Industry dominates based on their authority. Decisions that have been taken include: approval of the proposed program, collaboration with stakeholders relating to the development of craft industry centers, and resolving constraints in program implementation. From the interview with Mr. Ade (Head of PT Telkom's Responsi Division, 20 December 2019) data was obtained:

".. PT. Telkomsel as a stakeholder in the UMKM development program gets the authority to manage and develop the marketing field online. From the results that have been agreed upon, we have formed a program called Digital UKM Village as an effort that is expected to be able to make changes and can be utilized by craftsmen so that they can better market their craft products via digital. Besides that we also continue to communicate with the government and craftsmen so that they can continue to work well together in accordance with the agreement ... "

\section{Information Sharing}

Information sharing about the UKM Digital Village program is done formally and informally. Formally information sharing is conducted in meetings, training and FGD forums. Informally, information sharing is carried out in activities in the field such as during mentoring. In addition, information sharing is also done through social media, in this case via WhatsApp. In an interview with Mr. Juwahir, S.E., M.M., as the Head of the Small and Medium Enterprises Division, data was obtained that communication was conducted in two directions in various forums. Information submitted from the Office of Cooperatives, UKM, and Industry related to regulations, government programs, and various opportunities for developing the craft industry. Information submitted by PT. Telkom specifically deals with the UKM Digital Village program. The information 
Page 611-623. ISBN: 978-602-6 988-75-1

Web Jurnal Online: jurnal.unmuhjember.ac.id

By: Dian Eka Rahmawati; Samini Collaborative Governance Perspective In The Development of Micro Small and Medium Businesses (UMKM) in Bantul Regency 2017-2018

submitted by craftsmen is related to the problems of developing the craft industry. The Office of Cooperatives, UKM, and Industry also assigns assistants to assist and monitor the progress of the business as well as all forms of problems faced (interview 5 November 2018).

\section{Access to resources}

Access to resources related to financial or capital resources, human resources, and technical skills. Access to resources has obstacles in terms of human resources and technical skills that support the UKM Digital Village program. From the Office of Cooperatives, UKM, and Industry the constraints of human resources are in the form of limited number of staff. From PT Telkom there are relatively no resource constraints. Whereas from the craftsmen the constraints of human resources in the form of limited ability or technical ability to implement e-commerce as part of the UKM Digital Village program. PT. Telkom and Dinas have conducted training, but craftsmen still have difficulty applying e-commerce to market their products, so in the end the coconut shell craftsmen in Sanden Subdistrict are reluctant to use the application of the UKM Digital Village program again.

Based on the data and analysis above, the performance of eight indicators of the collaborative governance model of DeSeve, in the UKM Digital Village program between the Office of Cooperatives, UKM, and Industry, PT Telkom and craftsmen can be categorized as follows:

Table 4

Performance Indicators of Collaborative Governance in UKM Digital Village Program

\begin{tabular}{|l|l|l|l|}
\hline No & Indicators & Optimal & Less Optimal \\
\hline 1 & Network structure & V & \\
\hline 2 & Commitment to a common purpose & & V \\
\hline 3 & Trust among participants & & V \\
\hline 4 & Governance & V & \\
\hline 5 & Access to authority & V & \\
\hline 6 & Distributive accountability and responbility & V & \\
\hline 7 & Information sharing & V & \\
\hline 8 & Access to resources & & V \\
\hline
\end{tabular}

Sources: processed from interview data 
Proceeding ICOGISS 2019

Page 611-623. ISBN: 978-602-6 988-75-1

Web Jurnal Online: jurnal.unmuhjember.ac.id

By: Dian Eka Rahmawati; Samini

Collaborative Governance Perspective In The Development of Micro Small and Medium

Businesses (UMKM) in Bantul Regency 2017-2018

\section{CONCLUSION}

Based on the findings of the data and the results of the analysis it can be concluded that the collaborative governance process in the development of UMKMs in Bantul Regency in 2017-2018 has been running but has not been maximized. Improvement efforts are still needed on several indicators so that they can achieve the goal of collaborating on developing UMKMs.

The results of the eight collaborative governance process indicators show: 1) The network structure involves 3 actors, namely the Office of Cooperatives, UKM, and industry, PT Telkom, and craftsmen. Network structure and communication patterns are horizontal, each actor is in an equal position, there is no vertical hierarchy, all network members have the same position. 2) Commitment to a common purpose is based on the purpose of developing the craft industry. Commitments between the Cooperative, UKM, and Industry Service with PT. Telkom were agreed in the form of the MoU and the UKM Digital Village Program. Commitment to a common at the beginning of collaboration is quite strong because it is based on the purpose or reason for the collaboration, namely the development of UMKMs. But in its development, the commitment of craftsmen weakened because what they expected in the Digital UKM Village Program was not fulfilled. 3) Trust among participants is built through communication, but from the handicraftsmen they experience a decrease in trust in other actors because the programs implemented cannot solve their problems and have not yet obtained other, more effective solutions. 4) Governance is regulated through collaborative implementation regulations namely Law no.20 of 2008, regent regulation No.81 of 2015, and MoU between Cooperative, UKM, and Industry Services with PT. Telkom number: 92 / PK / BT / year 2016/2017 which is valid until 2019. 5) Access to authority is indicated by the existence of clear procedures and authority between the three actors in the program. The procedures provided are such as operational cooperation, joint venture, progress in the field of UMKMs, and the last is profit sharing (the benefit of each party) and the existing reality is deemed not achieved because the program being implemented has not been maximized. 6) Distributive accountability and responbility is dominated by the Office of Cooperatives, UKM, and Industry. The Cooperative Office for UKMs and industry has broader authority in considering and making decisions. then when problems occur, they will be accounted for maximally. 7) Information sharing is done formally in meetings, training, and FGD forums, also conducted informally in activities in the field such as during mentoring. Information dissemination is also done through social media. 8) Access to resources experiences obstacles from the aspect of human resources, especially from the aspect of quantity and technical skills from the Office of Cooperatives, UKM, and Industry and craftsmen who support the UKM Digital Village program. 
Proceeding ICOGISS 2019

Page 611-623. ISBN: 978-602-6 988-75-1

Web Jurnal Online: jurnal.unmuhjember.ac.id

By: Dian Eka Rahmawati; Samini

Collaborative Governance Perspective In The Development of Micro Small and Medium

Businesses (UMKM) in Bantul Regency 2017-2018

\section{REFERENCE}

Ansel, Christopher K, 2003, Community Embeddesness and Collaborative Governance in the San Francisco Bay Area Environmental Movement: Relational Approaches to Collective Action, Oxford Univesity Press.

Ansell, Chris, \& Alison Gash, 2008, Collaborative Governance in Theory and Practice, Journal of Public Administration Research and Theory, Vol.18 No.4, 543 - 571.

Andranovic, Greg, 1995, Achieving Concensus in Public Decision Making: Applying Interest Based Problem-Solving to the Challenges of Intergovernmental Collaboration, Journal of Applied Behavioral Research 31:4220-45.

Ardiyanti, Linda; Suryadi; Endah Setyowati, 2015,. Strategi Pemberdayaan Pengrajin Bordir melalui Kegiatan Ekonomi Kreatif (Studi pada Asosiasi Bordir Kel. Pogar Kec. Bangil dan Dinas Perindustrian dan Perdagangan Kab. Pasuruan). Jurnal Adminstrasi Publik (JAP), 3 (5).

Badruddin, Rudi, 2012, Mengembangkan UMKM dengan OVOP, Harian Kedaulatan Rakyat, Desember 2012.

Bryson, John S. and Other, 2006, The Design and Implementation of Cross- Sector Collaborations : Propositions from the Literature. Public Administration Review. December 2006. Special Issue : 44-55.

Conyers, Diana, 1994, Perencanaan Sosial di Dunia Ketiga: Suatu Pengantar, Gadjah Mada University Press, Yogyakarta.

Dwiyanto, Agus, 2011, Manajemen Pelayanan Publik : Peduli, Inklusif dan Kolaboratif, Edisi Kedua, Gadjah Mada University Press, Yogyakarta.

Hetifah, S.J Sumarto, 2003, Inovasi, Partisipasi dan GoodGovernance: 20 Prakarsa Inovatif dan Partisipatif di Indonesia. Yayasan Obor Indonesia, Jakarta.

Jasmadi, Saktiawan Natas, 2011. Peran Musrembang dalam Proses Perencanaan Pembangunan di Kabupaten Polewali Mandar. Skrripsi, Universitas Hassanudin Makassar.

Rahmawati., Dian Eka, 2014, Diktat Metode Penelitian Sosial, Universitas Muhamadiyah Yogyakarta.

Said, Muhammad Farid, 2015, Strategi Pemberdayaan Umkm Pada Dinas Koperindag Kabupaten Maros (Studi Kasus Pada Sektor Perdagangan). Skripsi, Universitas Hassanudin Makassar.

Subarsono, Agustinus, 2013, Kebijakan Publik dan Pemerintahan Kolaboratif: Isu-Isu Kontemporer, Gava Media, Yogyakarta.

Sugiyono, 2013, Metode Penelitian Kuantitatif Kualitatif, Alfabeta, Bandung.

\section{Dasar hukum :}

Undang-undang Nomor 20 Tahun 2008 tentang UMKM

Undang-undang nomor 25 Tahun 1992 tentang Perkoperasian 
Proceeding ICOGISS 2019

Page 611-623. ISBN: 978-602-6 988-75-1

Web Jurnal Online: jurnal.unmuhjember.ac.id

By: Dian Eka Rahmawati; Samini

Collaborative Governance Perspective In The Development of Micro Small and Medium

Businesses (UMKM) in Bantul Regency 2017-2018

\section{Website}

https://bantulkab.go.id, diakses pada 20 Oktober 2018 pukul 20.00 WIB

http://www.depkop.go.id/berita-informasi/data-informasi/data-umkm , diakses 9 Oktober 2018 pukul 20:21 WIB

https://diskukmp.bantulkab.go.id/ , diakses pada 15 Oktober 2018 pukul 15.20 WIB

http://kec-sanden.bantulkab.go.id/, diakses pada 10 Oktober 2018 pukul 13.00 WIB

https://www.kampungukmdigital.com/, diakses pada 20 Oktober 2018 pukul 20.00 WIB 